\title{
PHYSICOCHEMICAL ANALYSES INDICATED TO THE QUALITY CONTROL OF ROYAL JELLY WITH HONEY ${ }^{1}$
}

\author{
Lucila Coelho PAMPLONA², Ricardo A. B. AZEDO², Karla Cristina L. S. OLIVEIRA²,

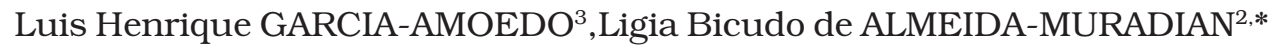

\section{SUMMARY}

Royal jelly (RJ) is used as a revitalizing tonic. In order to avoid rejection to its acid taste, it is added to honey. There are regulations for honey and for royal jelly separately but not for the mixture. The objective of this work is, therefore, to verify if the same methods used for pure honey quality control can be used for honey mixed with royal jelly and also the presence of RJ through 10-HDA determination. The methods used were: moisture, reducing sugars, apparent sucrose, ash, hydroxymethylfurfural, insoluble solids, diastase activity, acidity and 10-HDA. Samples were prepared by adding 0-100\% of RJ in honey. The results showed that the ash method was the only suitable one to all the samples. The acidity analysis (direct titration) was suitable to $0-30 \% R J$ samples; the reducing sugar analysis was suitable to $0-20 \%$ RJ samples. Concerning moisture analysis the refractometric method is suitable to 0-10\% RJ and the Infra Red method is suggested to be used for samples with more than $10 \%$ RJ. The methods for diastase activity, HMF, apparent sucrose and insoluble solids were inadequate for all samples with RJ. The presence of RJ in the samples was confirmed by the 10-HDA analyses. Keywords: honey; royal jelly; analysis; bee products; honey with royal jelly; quality control.

\section{RESUMO}

ANÁLISES FÍSICO-gUÍMICAS INDICADAS PARA O CONTROLE DE QUALIDADE DE MEL COM GELÉIA REAL. A geléia real (GR) é utilizada como produto revitalizante com sabor ácido e adstringente. Para evitar rejeição a este sabor, existem misturas de mel com GR. Existe legislação específica para o mel e para a GR separadamente, mas não para a mistura. Os objetivos do trabalho são: verificar se os métodos usados para o controle de qualidade do mel puro podem ser utilizados no controle do mel com GR e verificar a presença de GR pela determinação do 10-HDA. As análises incluíram: umidade, açúcares redutores, sacarose aparente, cinzas, hydroxymethylfurfural, sólidos insolúveis, atividade diastásica, acidez e 10-HDA. As amostras foram preparadas com 0-100\% de GR no mel. Os resultados obtidos sugerem que dos métodos citados na legislação do mel somente o de cinzas foi adequado para todas as amostras. A análise de acidez (titulação direta) foi adequada de 0-30\%GR; açúcares redutores 0-20\%GR; umidade (método refratométrico) 0-10\%GR e sugere-se o método de secagem por IV para as demais amostras. Os métodos para as análises da atividade diastásica, HMF, sacarose aparente e sólidos insolúveis foram inadequados para as amostras com GR. A presença de GR nas amostras foi comprovada pela análise do10-HDA.

Palavras-chave: mel; geléia real; análise; produtos apícolas; mel composto; controle de qualidade.

\section{1 - INTRODUCTION}

Honey mixed with other bee products is usually found in retail markets, being honey with propolis and royal jelly the most common. All of them are sold by the authorization of the Ministry of the Agriculture, and although there are no technical regulations for identity and quality to determine the necessary parameters to guarantee the authenticity or adulteration to these products they are frequently available for consumption.

Basically honey is a complex mixture of highly concentrated sugars whose chemical composition has been the subject of bibliographic revisions such as those made by CAMPOS [9] and SERRANO [22]. Besides the soluble sugars honey also contains organic acids, enzymes, vitamins, acetilcholine flavonoids, minerals and other organic compounds that provide its color, smell and taste [1].

\footnotetext{
Recebido para publicação em 02/04/2003. Aceito para publicação em 05/10/2004 (001085).

2. Departamento de Alimentos e Nutrição Experimental, Faculdade de Ciências Farmacêuticas da USP. Av. Prof. Lineu Prestes 580,Bloco 14, CEP:05508-900, São Paulo, SP, Brasil. Email: ligiabi@usp.br.

3. Centro Universitário Nove de Julho.

* A quem a correspondência deve ser enviada.
}

Honey from other countries has had its composition studied by several authors such as WHITE [25], HAYDAK [14] and SERRANO [22].

Royal jelly is secreted by the young bees and it is an important product for the bee hive serving as food for developing larva, for worker bees and for the drones (until $3^{\text {rd }}$ day of larval stage) and for the queen bee during its whole life $[3,8,23]$.

The vitality provided to the queen bee by the diet rich in royal jelly has attracted many consumers who search for a long healthy life. Some of its effects on human beings are: memory, physical performance and skin improvement. Furthermore, royal jelly also has antibiotic and antiviral action [17, 21].

Royal jelly has a complex composition of proteins, amino acids, organic acids, sterols, phenols, sugars, minerals and other components [26]. The main component of the lipidic fraction [4] is 10-hydroxy-2decenoic acid (10-HDA), considered the most important active principle $[11,13,16,18,20]$ in the royal jelly. The concentration of 10-HDA can be considered as an index of freshness and quality of the products that contain royal jelly serving as a parameter for its quality control $[2,11,16,19]$.

Royal jelly has been mixed with honey for a better acceptance to the consumers because of its acid taste. 
Also the presence of honey can contribute to the conservation of the royal jelly at room temperature.

In Brazil, there is a regulation for honey [6] and for royal jelly [5] separately but not for their combination. A provisional regulation was published for honey mixed with other bee products in 2001 [7] but the final regulation has not been published yet. However, neither the methods of analysis nor the standards of identity and quality to be used in these products quality control were mentioned

The objectives of this paper are: to verify if the same methods used in honey quality control regulation (Instrução Normativa n. 11 de Outubro de 2000) [6] can be applied for royal jelly mixed with honey and to confirm the presence of royal jelly trough 10-HDA analysis.

\section{2 - MATERIAL AND METHODS}

\section{1 - MATERIAL}

Samples of pure royal jelly and pure honey were obtained directly from beekeepers and marts under the federal authorization and supervision. All the products have a seal labeled on them - SIF (Serviço de Inspeção Federal). The mixture of royal jelly with honey was made in laboratory in the proportions described in Table 1.

TABLE 1. Proportions of royal jelly mixed with honey.

\begin{tabular}{cc}
\hline Samples & Royal Jelly $(\%)$ \\
\hline 1 (Pure Honey) & 0 \\
2 & 10 \\
3 & 20 \\
4 & 30 \\
5 & 40 \\
6 & 50 \\
7 & 60 \\
8 & 70 \\
9 & 80 \\
10 & 90 \\
11 (Pure royal jelly) & 100 \\
\hline
\end{tabular}

\section{2 - METHODS}

\subsection{1 - Methods used for pure honey and royal jelly mixed with honey}

Physicochemical methods, cited in the Brazilian honey regulation (Instrução Normativa no 11 de 20 de Outubro de 2000) [6] were used as follows: free acidity, reducing sugars, diastase activity, ash, hydroxymethylfurfural (HMF), apparent sucrose and insoluble solids.

The method used for 10-HDA was based in the method cited in the Brazilian regulation of royal jelly [5] substituting the Shimadzu® ODS-H column (C18-H reverse phase, dimension $150 \times 4,0 \mathrm{~mm}$ ) for Vydac ${ }^{\circledR}$ ODS column (C18 reverse phase, dimension $250 \times 4,6 \mathrm{~mm})$.
The method for moisture analysis used was the infrared moisture analyzer, according to GARCIAAMOEDO \& ALMEIDA-MURADIAN [12].

\subsection{2 - Methods used for pure royal jelly}

Physicochemical analyses, cited in the Brazilian royal jelly regulation [5] were used as follows: Fehling method for reducing sugars and apparent sucrose [15], gravimetric method for ash content [16] titrimetric method for free acidity [15] and HPLC method for 10HDA [5, 11].

Infrared moisture analyzer was used for moisture content analysis according to GARCIA-AMOEDO \& ALMEIDA-MURADIAN [12].

\subsection{3 - Statistical analysis}

Statistical analysis was made using the software STATISTICA for Windows (Statsoft. Inc, 1995, Tulsa, USA), as described by COSTA NETO [10].

\section{3 - RESULTS AND DISCUSSION}

For the evaluation of the pure honey and pure royal jelly, physicochemical analyses were made as follows:

\section{1 - Pure royal jelly}

The analytical results obtained and the values of the Brazilian royal jelly regulation are presented in Table 2.

TABLE 2. Mean values of the physicochemical analyses of pure royal jelly and the values of the Brazilian royal jelly regulation.

\begin{tabular}{ccc}
\hline Parameters & Results $^{\star}$ & Brazilian regulation \\
\hline Reducing sugars $(\mathrm{g} / 100 \mathrm{~g})$ & $14.9 \pm 0.2$ & Minimum of 10 \\
Ash $(\mathrm{g} / 100 \mathrm{~g})$ & $0.89 \pm 0.02$ & Maximum of 1.5 \\
Free acidity $(\mathrm{mg} \mathrm{KOH} / \mathrm{g})$ & $15.4 \pm 0,1$ & 23 to 53 \\
Apparent Sucrose $(\mathrm{g} / 100 \mathrm{~g})$ & $0.0 \pm 0.0$ & Maximum of 5.0 \\
Moisture $(\mathrm{g} / 100 \mathrm{~g})$ & $64.5 \pm 0.1$ & 60 to 70 \\
$10-$ HDA $(\mu \mathrm{g} / 100 \mathrm{~g})$ & $4.98 \pm 0.12$ & Minimum of 2 (dry basis) \\
\hline
\end{tabular}

"Mean \pm standard deviation, $\mathrm{n}=3$.

Comparing the values obtained for moisture, reducing sugars, ash, apparent sucrose and 10-HDA with the Brazilian regulation values it can be verified that all the results are in accordance with this regulation (Instrução Normativa n. 3/2001) [5], except from the values obtained for the free acidity that are lower than the limits recommended. Similar results were obtained by GARCIA-AMOEDO [11] who analyzed royal jelly samples from São Paulo city, Brazil in 1999.

\section{2 - Pure honey}

The analytical results obtained and the values of the Brazilian pure honey regulation are presented in Table 3. 
TABLE 3. Results from the physicochemical analyses of pure honey and the Brazilian regulation parameters.

\begin{tabular}{ccc}
\hline Parameters & Results $^{*}$ & Brazilian regulation \\
\hline Free acidity $(\mathrm{mEg} / \mathrm{Kg})$ & $32.4 \pm 0.2$ & Maximum of 50 \\
Reducing sugars $(\mathrm{g} / 100 \mathrm{~g})$ & $71.8 \pm 0.8$ & Minimum of 65 \\
Diastase activity & 9.64 & Minimum of 8 \\
Ash $(\mathrm{g} / 100 \mathrm{~g})$ & $0.19 \pm 0.02$ & Minimum of 0.6 \\
$\mathrm{HMF}(\mathrm{mg} / \mathrm{kg})$ & $22 \pm 2$ & Maximum of 60 \\
Apparent sucrose $(\mathrm{g} / 100 \mathrm{~g})$ & $1.44 \pm 0.02$ & Maximum of 6 \\
Insoluble solids $(\mathrm{g} / 100 \mathrm{~g})$ & $0.008 \pm 0.002$ & Maximum of 0.1 \\
Moisture $(\mathrm{g} / 100 \mathrm{~g})$ & $16.5 \pm 0.1$ & Maximum of 20 \\
\hline
\end{tabular}

Mean \pm standard deviation, $\mathrm{n}=3$.

All the results (Table 3 ) are in accordance with the limits proposed by the Brazilian regulation [6], being similar to those obtained by VILHENA \& ALMEIDAMURADIAN [24].

\section{3 - Honey mixed with royal jelly}

The results for physicochemical analyses of honey mixed with royal jelly are presented in Table 4.

TABLE 4. Results from physicochemical analyses of honey mixed with royal jelly.

\begin{tabular}{cccccccc}
\hline Sample & DT & IT & RS & Ash & IS & 10 -HDA & Moisture \\
\hline Honey & $1.31 \pm 0.01$ & -- & $71.8 \pm 0.8$ & $0.19 \pm 0.02$ & $0.008 \pm 0.002$ & 0.00 & $16.5 \pm 0.1$ \\
Honey & & & & & & & \\
with \% & & & & & & & \\
RJ & & & & & & & \\
10 & $3.4 \pm 0.1$ & $4.3 \pm 0.2$ & $61.9 \pm 0.8$ & $0.25 \pm 0.03$ & $0.34 \pm 0.01$ & $0.13 \pm 0.01$ & $22.60 \pm 0.30$ \\
20 & $4.2 \pm 0.0$ & $5.2 \pm 0.1$ & $58.8 \pm 0.8$ & $0.36 \pm 0.03$ & $0.38 \pm 0.02$ & $0.34 \pm 0.04$ & $24.25 \pm 1.05$ \\
30 & $5.8 \pm 0.1$ & $6.8 \pm 0.2$ & $38.2 \pm 0.6$ & $0.41 \pm 0.03$ & $0.26 \pm 0.02$ & $0.51 \pm 0.03$ & $26.85 \pm 0.85$ \\
40 & $6.6 \pm 0.2$ & $6.9 \pm 0.1$ & $22.6 \pm 1.1$ & $0.49 \pm 0.04$ & $0.40 \pm 0.02$ & $0.67 \pm 0.03$ & $33.85 \pm 0.85$ \\
50 & $8.0 \pm 0.1$ & $8.7 \pm 0.1$ & $28.5 \pm 2.2$ & $0.58 \pm 0.04$ & $0.44 \pm 0.02$ & $0.85 \pm 0.01$ & $39.85 \pm 0.15$ \\
60 & $10.1 \pm 0.5$ & $10.7 \pm 0.4$ & $19.3 \pm 1.0$ & $0.66 \pm 0.02$ & $0.76 \pm 0.05$ & $1.08 \pm 0.11$ & $46.10 \pm 0.20$ \\
70 & $10.6 \pm 0.2$ & $11.4 \pm 0.2$ & - & $0.73 \pm 0.05$ & $0.52 \pm 0.05$ & $1.57 \pm 0.03$ & $50.45 \pm 0.95$ \\
80 & $12.2 \pm 0.1$ & $12.8 \pm 0.0$ & - & $0.80 \pm 0.05$ & $1.05 \pm 0.06$ & $1.75 \pm 0.03$ & $55.9 \pm 0.14$ \\
90 & $14.5 \pm 0.6$ & $15.1 \pm 0.6$ & - & $0.87 \pm 0.05$ & $0.84 \pm 0.04$ & $1.91 \pm 0.05$ & $59.1 \pm 0.10$ \\
RJ & $11.0 \pm 0.1$ & $11.4 \pm 0.0$ & $14.9 \pm 0.2$ & $0.89 \pm 0.02$ & -- & $1.77 \pm 0.04$ & $64.5 \pm 0.1$ \\
\hline
\end{tabular}

DT- free acidity by direct titration $(\mathrm{mg} \mathrm{NaOH} / \mathrm{g})$; IT - free acidity by indirect titration

RS - reducing sugars (g/100g); Ash (g/100g); IS - insoluble solids (g/100g); RJ - royal jelly.

\subsection{1 - Free acidity}

The obtained values concerning free acidity (direct titration in Table 4) showed that the results increased as long as the percentage of royal jelly increased in the samples. However, as problems at the endpoint visualization occurred from 30\% RJ to 100\% RJ samples, the indirect titration was used. Comparing these two methods and using statistical analysis (Pearson's correlation $r=0.998$ ) it could be verified that direct titration results are significantly lower in acidity values than those obtained by indirect titration. Once that both the regular Brazilian legislation to pure honey and to pure royal jelly do not specify which titration method should be used, the suggested one for standardizing is the indirect titration for mixed samples, as recommended by GARCIA-AMOEDO [11].

\subsection{2 - Reducing sugars}

According to the official method for pure honey adopted by the Brazilian regulation [6], a constant volume of $5 \mathrm{~mL}$ of titration solution during Fehling's reaction is usually used. However, samples from 30\% $\mathrm{RJ}$ requested higher volumes than those recommended by the method and from $70 \% \mathrm{RJ}$ samples the endpoint did not occur even if $100 \mathrm{~mL}$ of titration solution was added. Thus, this method is suggested only for $0-30 \%$ RJ samples.

\subsection{3 - Diastasic activity}

Only the samples of pure honey (9.64) and 10\% RJ (8.75) could be analysed using the official method [6]. Samples from $20 \%$ of $\mathrm{RJ}$ presented precipitation in the solution, harming the absorption measurement.

\subsection{4 - Ash}

The official gravimetric method [6] for ash analysis was suitable for all the samples being the ash and royal jelly values increased proportionally (Table 4).

\subsection{5 - Hydroxymethylfurfural (HMF)}

The official hydroxymethylfurfural method [6] was suitable only for pure honey. For samples with RJ the method was not suitable because the results were sometimes negative and not constant.

\subsection{6 - Apparent sucrose}

The official method for apparent sucrose [6] was suitable only for pure honey. For samples with RJ the method was suitable only for pure honey. For samples with RJ the method was not suitable because the results sometimes were negative and not constant.

\subsection{7 - Insoluble solids}

The official method for insoluble solids analysis [6] had to be modified concerning the weight of samples (from $20 \mathrm{~g}$ to $1 \mathrm{~g}$ ), as royal jelly presents much higher amount of insoluble solids than pure honey what causes filtration blockage. In Table 4 it can be seen that insoluble solids results increased with the presence of royal jelly in honey, but it was not proportional to the percentage of royal jelly added. Thus, this method seems to be inadequate to analyze samples with royal jelly.

\subsection{8 - Moisture}

The Brazilian regulation for pure honey [6] recommends the refractometric method for moisture analysis which proved to be suitable only for $0-10 \% \mathrm{RJ}$ samples. However, as the samples ranking to $20-100 \%$ $\mathrm{RJ}$ did not match suitable values in the Chataway table, it was necessary to use the infrared gravimetric method instead. 
As commercial samples usually contain around $2 \%$ royal jelly, the refractometric method can be applied.

\subsection{9 - 10-HDA}

Table 4 shows that the enhancement of the royal jelly percentage results in a proportional increase of the 10-HDA values but the values obtained for RJ (1.77), 80\%RJ (1.75) and 90\% (1.91) were not significantly different (t-Student statistical analysis).

\section{4 - CONCLUSIONS}

Among all the official methods, the gravimetric method for ash analyses was the only suitable one for all the samples.

The acidity analysis by direct titration could be used for samples ranking $0-30 \% \mathrm{RJ}$ and the indirect titration was suitable for all the samples with RJ.

The reducing sugars determination was suitable for samples ranking $0-20 \% \mathrm{RJ}$.

The refractometric method for moisture determination was suitable for samples ranking from 0-10\% RJ and the Infrared gravimetric method was suitable for all samples with RJ.

The methods for diastasic activity, HMF, apparent sucrose and insoluble solids were inadequate for samples with royal jelly.

Regarding commercial samples, which usually have about $2 \%$ of $\mathrm{RJ}$, the following methods of the regulation can be used: acidity, reducing sugars, moisture and ash.

The presence of royal jelly in samples was confirmed through chromatographic analysis of 10-HDA.

\section{5 - REFERENCES}

[1] ALMEIDA-MURADIAN, L.B., PAMPLONA, L., BERA, A., VILHENA, F., CHIEBAO, H., COLli, C. Minerais de méis comercializados no Estado de São Paulo. In: ENCONTRO SOBRE ABELHAS, 5, Ribeirão Preto, 2002. Anais. Ribeirão Preto: FFCL/RP/USP, 2002. p. 294.

[2] ANTINELLI, J.F., ZEGGANE, S., DAVICO, R., ROGNONE, C., FAUCON, J.P., LIZZANI, L. Evaluation of (E)-10hydroxydec-2-enoic acid as a freshness parameter for royal jelly. Food Chem., v. 80, p. 85-89, 2003.

[3] BLOODWORTH, B.C.; HARN, C.S.; HOCK, C.T.; BOON, Y.O. Liquid chromatographic determination of trans10-hydroxy-2-decenoic acid content of commercial products containing royal jelly. J. AOAC Int., v. 78, n. 4, p. 1019-1023, 1995.

[4] BLUM, M.S.; NOVAK, A.F.; TABER III, S. 10-hydroxy$\mathrm{D}^{2}$-decenoic acid, an antibiotic found in royal jelly. Nature, v. 130, p. 452-453, 1959.

[5] BRASIL. Instrução Normativa n.3 de 19 de janeiro de 2001. Regulamentos Técnicos de Identidade e Qualidade de apitoxina, cera de abelha, geléia real, geléia real liofilizada, pólen apícola, própolis e extrato de própolis. Disponivel em: http://www.agricultura.gov.br/ sda/dipoa. Acesso em 5/4/2001.
[6] BRASIL. Instrução Normativa n.11, de 20 de Outubro de 2000. Regulamento Técnico de Identidade e Gualidade do Mel [online]: http:// www. agricultura.gov.br/ sda/dipoa/anexo_instrnorm 11.htm.

[7] BRASIL, Leis, Decretos, etc. Resolução no 01, de 19 de junho de 2001. [online]: http://www.agricultura.gov. br/sda/dipoa/resolucao01_190601.htm

[8] BONVEHÍ, J.S. Estudio de la proteina y aminoacidos libres de la jalea real. Anales de Bromatologia, v. 42, n. 2, p. 353-365, 1990.

[9] CAMPOS, M.G.R. Contribuição para o estudo de mel, pólen, geléia real e própolis. Bol. Fac. Farm. Coimbra, v. 11, n. 2, p. 17-47, 1987.

[10 ] COSTA NETO, P.L.O. Estatística. São Paulo: Edgard Blücher, 1977, 262p.

[11] GARCIA-AMOEDO, L.H. Geléia real: análises físicoquímicas e químicas úteis para caracterização e detecção da autenticidade ou adulteração do produto. São Paulo, 1999. 60p. Tese (Mestrado) - Faculdade de Ciências Farmacêuticas, Universidade de São Paulo.

[12] GARCIA-AMOEDO, L.H. ALMEIDA-MURADIAN,L.B. Comparação de metodologias para a determinação de umidade em geléia real. Guim. Nova, v. 25, n. 4, p. 676-679, 2002

[13] GARCIA-AMOEDO,L.H, ALMEIDA-MURADIAN,L.B.. Determination of trans 10-hydroxy-2-decenoic acid (10HDA) in Brazilian royal jelly. Ciênc. Tecnol. Aliment. v. 23, Supl., p. 62-65, 2003.

[14] HAYDAK, M.H. Biological properties of honey. In: CRANE, E. Honey: a comprehensive survey. London: Heinemann, 1975. p. 258-266.

[15] INSTITUTO ADOLFO LUTZ. Normas analíticas do Instituto Adolfo Lutz. São Paulo: IAL, 1985, 533p.

[16] KOSHIO,S., ALMEIDA-MURADIAN,L.B. Aplicação da CLAE para determinação do ácido 10-hidróxi-2decenóico (10-HDA) em geléia real pura e adicionada a mel brasileiro. Quim. Nova, São Paulo, v. 26, n. 5, p. 670-673, 2003.

[17] KRELL, R. (1996). Value-added products from beekeeping. FAO Agricultural Services Bulletin 124 (pp. 87-113). Rome: Food and Agriculture Organization.

[18] MAEDA, T.; KURODA, H.; MOTOYOSHI, K. Nippon Hifuka Gakkai Zasshi, v. 98, n. 4, p. 469, 1988 apud JIA, L.; ZHANG, H.X.; HU, Z.D. Separation and determination of 10-hydroxy-2-decenoic acid in royal jelly by capillary electrophoresis. Chromatographia, v. 41, n. 9/10, p. 605-609, 1995.

[19] MATSUI, M. [Decreasing effect of honey on hydroxy acids in royal jelly products]. Shokuhin Eiseigaku Zasshi, v. 29, n. 5, p. 297-300, 1988.

[20] MURATA T.; CHEN, Z.H.; ZOU,.L.S. Huaxue Tongbao, v.5, p.31, 1987 apud JIA, L.; ZHANG, H.X.; HU, Z.D. Separation and determination of 10-hydroxy-2-decenoic acid in royal jelly by capillar electrophoresis. Chromatographia, v. 41, n. 9/10, p. 605-609, 1995.

[21] PUTTKAMMER, E. Geléia real - métodos e técnicas de produção, coleta e armazenamento. Florianópolis: EPAGRI, 1994. 30p.

[22] SERRANO, R.B.; La miel. Edulcorante natural por excelencia. Alimentaria, n. 29, p. 29-35, 1994.

[23] TOWNSEND, G.F.; LUCAS, C.C. The chemical nature of royal jelly. Biochem. J., v. 34, p. 1155-1162, 1940.

[24] VILHENA,F., ALMEIDA-MURAdIAN,L.B. Análises físico-químicas de méis de São Paulo. Mensagem Doce, São Paulo, n. 53, p. 17-19, 1999. 
[25] WHITE, J.W. Composition of honey. In: CRANE, E. Honey: a comprehensive survey. London: Heinemann, 1975. p. 207-239.

[26] YANG, Y.F. Zhongcaoyao, v. 19, n. 11, p. 33, 1988 apud JIA, L.; ZHANG, H.X.; HU, Z.D. Separation and determination of 10-hydroxy-2-decenoic acid in royal jelly by capillar electrophoresis. Chromatographia, v. 41, n. 9/10, p. 605-609, 1995.

\section{6 - ACKNOWLEDGMENTS}

The authors of this study thanks to CNPq and FAPESP for financial support. 